\title{
Efforts to slacken antibiotic resistance: Labeling meat products from animals raised without antibiotics in the United States
}

\begin{abstract}
:
As bacteria and diseases spread due to climatic change, greater amounts of antibiotics will be used thereby exacerbating the problem of antibiotic resistance. To help slacken the development of resistant bacteria, the medical community is attempting to reduce unnecessary and excessive usage of antibiotics. One of the targets is the use of antibiotics for enhancing animal growth and promoting feed efficiency in the production of food animals. While governments can adopt regulations prohibiting nontherapeutic uses of antibiotics in food animals and strategies to reduce antibiotic usage, another idea is to publicize when antibiotics are used in food animal production by allowing labeled meat products. This paper builds upon existing labeling and marketing efforts in the United States to show how a government can develop a verified antibiotic-free labeling program that would allow consumers to purchase meat products from animals that had never received antibiotics.
\end{abstract}

Keywords: antibiotics; antibiotic resistance; meat products; labeling; consumers

\section{Introduction}

The rapid development of antibiotic-resistant bacteria is challenging the medical community and public health services (CDC, 2013). The U.S. Centers for Disease Control and Prevention 
(CDC) and the Food and Agriculture Organization consider antimicrobial resistance to be a serious world health threat (CDC, 2013; Food and Agriculture Organization, 2015). An estimated 700,000 people die each year due to antimicrobial resistance (O'Neill, 2014). With changes in temperatures and rainfall, climate-sensitive bacteria and diseases are projected to increase and spread to new areas, thereby exacerbating problems (Cash et al., 2014; Ni et al., 2014; Wang et al., 2015). The scientific community has advocated policies that would slacken the development of antibiotic-resistant bacteria (CDC, 2013; Center for Disease Dynamics, Economics \& Policy, 2016). One approach is to decrease antibiotic usage so that fewer numbers of bacteria are exposed to antibiotics and fewer resistant genes develop. Unnecessary usages of antibiotics have been identified, and recommendations to reduce usage are being implemented (White House, 2015).

A targeted area for reducing usage is the production of animals being raised for food, especially cows, pigs, and chickens (Centner, 2008; FDA, 2012, 2013, 2015; Van Boeckel et al., 2015). Agricultural producers are using nontherapeutic antibiotics to improve feed efficiency, to cause animals to gain weight, and to keep animals healthy (Cervantes, 2016). Moreover, without intervention, agricultural uses of antibiotics are projected to increase (Van Boeckel et al., 2015). Since several important antibiotics used in agriculture are also used to treat humans (Table 1), reductions in agricultural uses of antibiotics could be effective in slackening the development of antibiotic-resistant bacteria (Holmes et al., 2015).

Numerous efforts have been made to assist producers in minimizing antibiotic usage. In the United Kingdom, a non-governmental organization known as the Responsible Use of Medicines in Agriculture (RUMA) has issued guidelines for the coordinated and integrated approach to 
animal medicine usage. It has separate guidelines for poultry, pigs, cattle, sheep, and fish production (RUMA, undated). A review of the literature provides numerous other ideas for practices by producers, veterinarians, governments, and non-governmental organizations that may be employed to reduce antibiotic usage (Table 2). Although these ideas are being implemented in some areas of the world to decrease antibiotic usage, the problem of antibiotic resistance suggests that further efforts be encouraged.

Given the economic advantages accompanying nontherapeutic uses of antibiotics (Key and McBride, 2014), agricultural producers are not expected to voluntarily terminate their use. Rather, governmental requirements or financial incentives will be needed to reduce usage. The European Union banned certain antibiotics used in animal production in 1998 (EU Council Regulation, 1998). In the United States, the federal government adopted a veterinary feed directive rule in 2015 (FDA, 2015). Mandates set forth in the rule should help reduce some uses of antibiotics (Centner, 2016). However, U.S. federal regulations allow tolerance levels for some antibiotic residues in meat products (U.S. CFR, 2016, part 556). Thus, some consumers want a more specific guarantee that their meat products are "antibiotic free." Moreover, some consumers are willing to pay more to forgo meat products from animals receiving antibiotics.

An analysis of public attitudes in the United States suggests support for voluntary labeling of meat products from animals not receiving antibiotics (Valles, 2015). This offers vendors and governments an opportunity to do more to reduce the development of antibiotic-resistant bacteria by facilitating labels of antibiotic-free food products (Levitt, 2015; Wallinga, 2015). One idea is to facilitate the use of an "antibiotic-free" label on meat products from animals that never received antibiotics. An evaluation of a labeling controversy involving recombinant bovine 
somatotropin-free (rBST-free) milk products describes how antibiotic-free meat labels might accurately account for the nonuse of antibiotics. American judicial pronouncements on constitutional free speech rights lend support to developing labels for meat products that acknowledge the nonuse of antibiotics in the production of animals supplying the products.

This paper describes how antibiotic-free labels might assist in curtailing some uses of antibiotics in agriculture as a precursor to taking more definitive international action. As suggested by the Food and Agriculture Organization, international efforts may involve a stepwise approach under which countries implement elements "in accordance with their capacities" (Food and Agriculture Organization, 2015, p. 69). A proposal is offered to employ consumer health concerns about antibiotic resistance to garner support for a voluntary meat labeling program in countries with consumer interest in reducing antibiotic resistance. Consumers could abstain from purchasing meat products that come from animals that received antibiotics to reduce antibiotic usage. By slowing the evolution of antibiotic-resistant bacteria, antibiotics can maintain their effectiveness for longer periods to help compensate for the spread of pathogens due to climate change.

\section{U.S. Governmental oversight}

\subsection{Meat product labeling}

The public is concerned about the wholesomeness of their food and the production of animals providing their food. Some consumers do not want meat products that are associated with antibiotics, artificial hormones, drug residues, or how animals were fed, so want labels 
containing information about the nonuse of a production input or process (Abrams et al., 2010; Ortega et al., 2014; Stranieri and Banterle, 2014; Umberger et al., 2009). Under U.S. federal law, no unsafe antibiotic drug residues are allowed in meat products (U.S. CFR, 2016, tit. 21, § 510.110), and "sponsors of drugs containing any antibiotic intended for use in food-producing animals shall submit data for determining whether or not such antibiotics and their metabolites are present as residues in edible tissues, milk, and eggs from treated animals" (U.S. CFR, 2016, tit. 21, § 510.112). However, these provisions do not guarantee that meat products are antibiotic free (Baron et al., 2014), and some consumers remain unconvinced about the safety of meat products from animals that received antibiotics (Brewer and Rojas, 2008; Consumer Reports, 2012, p. 8).

Many consumers in developed countries also believe that agricultural uses of antibiotics are contributing to antibiotic resistance (Cervantes, 2015). In many cases, vendors and consumers are willing to pay extra for such meat products (McKendree et al., 2013; Payne et al., 2009; Sneeringer et al., 2015; Teillant and Laxminarayan, 2015). To preclude mislabeling, the U.S. Department of Agriculture (USDA) has adopted guidance for voluntary labeling of meat products regarding the nonuse of antibiotics. A label cannot say that a product is "antibiotic free" (USDA, undated), because scientific testing does not have the capacity to verify this claim (USDA, 2002). A label may say "no antibiotics added" (USDA, 2015a). Presumably, labels can also contain statements saying "no antibiotics administered" or "raised without antibiotics" (USDA, 2002). For many meat products, there is no information on their labels about whether antibiotics were administered in the production of animals providing the products (Consumer Reports, 2012, p. $14)$. 
Consumers can secure meat products from animals that were not administered antibiotics under the U.S. federal organic certification program (USDA, 2002). Products labeled as organic are verified by an independent third party. Yet several substances are allowed to be used in organic livestock production including biologics, chlorohexidine, and some parasiticides (U.S. CFR, 2016, tit. 7, § 205.603). While the organic certification program offers a mechanism for consumers to purchase meat products that were from animals not treated with antibiotics, the restrictive qualifications for organic products limit production options.

The USDA's Process Verified Program sets forth a procedure under which animals can be verified as not receiving antibiotics (USDA, 2016a). Recently, this program has been used to develop testing and verification processes to confirm that corn and soybeans are not genetically engineered (USDA, 2016b). The USDA's verification program using the International Organization for Standardization's ISO 9000 series standards for documented quality management systems could be employed to substantiate an antibiotic-free label for meat products. By announcing a product is "antibiotic free," the label would offer consumers a clear choice in purchasing meat products from animals raised without therapeutic or nontherapeutic antibiotics. The antibiotic-free label could augment current efforts to reduce the development of antibiotic-resistant bacteria.

\subsection{Misbranding legislation}

In the United States, multiple federal statutes address the truthfulness of labels on meat products (Table 3). The U.S. Food and Drug Administration (FDA) has been actively involved with the labeling of food products since the adoption of the Federal Food, Drug, and Cosmetic 
Act of 1938 (U.S. Statutes, 1938). A food product is misbranded if statements on its label or in its labeling are false or misleading. In addition, the absence of information relevant to the issue may cause labeling to be misleading. Thus, misbranding precludes labeling information that without further details might be expected to mislead. Any person misbranding a product may be criminally prosecuted by the federal government (U.S. Code, 2012, tit. 21, §§ 333, 352). The act does not contain a provision that allows consumers to bring lawsuits for misbranding (Merrell Dow Pharmaceuticals Inc. v. Thompson, 1986).

Mislabeling that results in unfair competition, fraud, or deception may violate the federal Lanham Act (U.S. Statutes, 1946). This act allows competitors to bring lawsuits for unfair competition due to misleading advertising or labeling. To protect markets, firms will sue competitors with mislabeled products (POM Wonderful LLC v. The Coca-Cola Company, 2014). For meat labeling, Congress has authorized the Secretary of the USDA to oversee labels that may be false or misleading. The Federal Meat Inspection Act prohibits false and misleading labels (U.S. Code, 2012, tit. 21, § 678) and the Poultry Products Inspection Act precludes misbranding (U.S. Code, 2012, tit. 21, § 458). However, none of these federal acts contains authority for consumers to sue for false and misleading labels (Sanderson Farms, Inc. v. Tyson Foods, Inc., 2008b). Rather, consumers may bring actions against marketers who employ false and misleading advertising (Sanderson Farms, Inc. v. Tyson Foods, Inc., 2008a).

In the absence of a federal provision delineating a right for consumers to commence a civil action for mislabeling (Radis, 2015), most claims about mislabeled products are brought under U.S. state law. Due to the federal constitutional Supremacy Clause, state legislation cannot conflict with the federal legislation. However, none of the federal mislabeling legislation 
expressly preempts state legislation (Paben, 2015; Wyeth v. Levine, 2009). Because states have historic police powers, the U.S. Supreme Court concluded that state law was complementary to federal labeling law administered by the FDA (Wyeth v. Levine, 2009).

State legislatures have adopted an array of consumer legislation and some have provisions under which persons harmed by labels containing false or misleading information can bring a mislabeling action. In a case involving a label listing an ingredient as "evaporated cane juice" instead of "sugar," a California court concluded that the plaintiffs had advanced a mislabeling claim under California state law (Gitson v. Trader Joe's Company, 2014). In a case involving Natural Brew ${ }^{\circledR}$ Draft Root Beer, a federal court concluded the plaintiff could maintain claims for a breach of express warranty and violation of deceptive practices under New York law (Silva v. Smucker Natural Food, Inc., 2015).

\section{Vendor and restaurant actions}

Given the desire of some consumers to purchase meat products from animals that were not given antibiotics, American vendors and restaurants are making guarantees about the nonusage of antibiotics in animals that supply their meat products. Major meat vendors, especially of chicken products, have adopted programs to reduce or eliminate the use of antibiotics in animals providing their products. Pilgrim's Pride has an antibiotic policy under which some birds (chickens and turkeys) are raised without antibiotics (Pilgrim's Pride, 2015), and recently announced that 25 percent of its chicken products would be antibiotic-free by 2019 (Bunge, 2015). Perdue Farms, Inc. has been actively helping producers to eliminate antibiotics, and markets more than one-half of its chicken products from birds that never received antibiotics 
(Perdue Farms, Inc., 2015; Strom, 2015c). Tyson Foods has reduced the use of human antibiotics for treating broiler chickens by 80 percent since 2011 (Tyson Foods, 2016), and is striving to eliminate human antibiotics from its broiler chicken production by 2017 (Strom, 2015b).

A 2015 study of the top U.S. restaurant chains found that many did not publically announce any policy limiting routine use of antibiotics in the raising of food animals supplying their products (Friends of the Earth et al., 2015). However, this is changing as some restaurants seek to position their image as socially conscious by not using products involving animals treated with antibiotics. Major restaurant chains and specialty restaurants are cognizant of the antibiotic issue and some are claiming their meat products come from animals that have not received antibiotics (Brown, 2015; Detar, 2015; Reichl, 2014; Strom, 2015c). For example, in 2015, McDonald's announced that it would begin using chickens that are not raised with antibiotics (Strom, 2015a)

As vendors and restaurants proceed to source meat products from animals that were never treated with antibiotics, questions arise as to what labels and claims can be made and their accuracy. Many firms simply announce they have instituted programs to reduce uses of antibiotics and identify projections for the future. They are aware of the federal and state misbranding provisions, so avoid making guarantees that current meat products come from animals that did not receive antibiotics. Yet, it is possible that the projections are being misinterpreted by some people who believe that current meat products came from animals not treated with antibiotics. Given the lack of any reliable guarantee by many of these public relations programs, consumer groups seek to develop mechanisms that would more succinctly identify products from animals not given antibiotics. One guarantee would be a label on meat products clearly telling consumers that the animal was not treated with antibiotics. 


\section{Establishing an antibiotic-free label}

\subsection{USDA's interpretation}

While some vendors and consumer groups support an antibiotic-free label, it currently is not available due to the USDA's stance that such a claim cannot be verified (USDA, 2002). The government's cautionary approach is due to the fact that animals treated with antibiotics may not have any residues in their bodies at the time of slaughter. This means that science-based testing methods do not have the capability of verifying that a meat product is from an animal that never was treated with antibiotics. Yet, the possibility exists that some other type of verification could justify an antibiotic-free label. The USDA allows verification methods for organic products, the absence of beta-agonists in meat products, non-hormone treated meat products, and process verification (USDA, 2015b, 2015c, 2016a). These other verification procedures mean that the absence of scientific testing does not require the prohibition of an antibiotic-free label.

In addition, recent scientific findings provide a second reason for differentiating meat products based on the nonuse of antibiotics. The research found that there is a compositional difference between meat products from animals treated with antibiotics and those not receiving antibiotics. Farms using a cephalosporin antibiotic had significantly higher counts of extended-spectrum ß-lactamases in slaughter pigs compared to farms not using the antibiotic that mediate resistance to extended-spectrum cephalosporins (Hammerum et al., 2014). Other research announced that the handling of meats harboring plasmid-encoded Ambler class $\mathrm{C}$ beta-lactamase genes may contribute to the increasing prevalence of third generation cephalosporin resistance (Voets et al., 2013). Moreover, extended-spectrum ß-lactamase-positive 
E. coli from animals may represent a reservoir of virulence and resistance genes, although resistance genes have not been associated as the direct cause of infections in humans (Wu et al., 2013). Because the use of antibiotics in food animals is encouraging the development of $E$. coli that are resistant to antibiotics and resistant bacteria on animal skin and in feces may come into contact with humans (Holmes et al., 2015), some people want to avoid meat products from animals receiving antibiotics.

Given vendors' desire for an antibiotic-free label and compositional differences between meat products produced from animals that were never administered antibiotics as opposed to animals receiving antibiotics, it may be contended that the USDA's prohibition of antibiotic-free labels interferes with vendors' free speech rights. Insights are offered by a judicial analysis of labels regarding the use of recombinant bovine somatotropin (rBST). This analysis of rBST labeling provides a legal foundation for asserting that meat vendors should be able to label products as antibiotic free.

\subsection{Judicial interpretation of "rBST free"}

The FDA's antipathy to labels saying that food products are free of something was expressed in its guidance on labeling products from cows treated with the artificial hormone rBST (FDA, 1994). The agency declined to allow labels saying "rBST free" due to concerns that such a statement could be false (FDA, 1994, p. 6280). Various legislative and legal controversies followed about labeling milk products so consumers would know whether the products came from cows that had been treated with rBST (Centner and Lathrop, 1997). The prohibition against the labeling of milk products as rBST free was accepted until the federal Sixth Circuit Court of 
Appeals reached a contrary result in adjudicating the International Dairy Foods Association $v$. Boggs (2010) lawsuit.

The Boggs lawsuit involved regulations adopted by the state of Ohio to curb misleading labeling of dairy products by prohibiting claims regarding the nonuse of rBST. The Ohio regulation said that the claim rBST free was false and misleading (Ohio Administrative Code, 2011). Dairy processor trade organizations objected to Ohio's new regulations and argued that the regulations violated their free speech rights guaranteed by the First Amendment to the U.S. Constitution. The Ohio regulations did not allow them to tell the public about their rBST-free dairy products (International Dairy Foods Association v. Boggs, 2010).

Since the Ohio regulation precluding an rBST-free claim was founded on the premise that the term misleads consumers about differences in milk, the issue before the Boggs court was whether there is a compositional difference. The FDA claimed that milk from cows treated with rBST and those not treated is the same so there is no compositional difference. This means that any label suggesting a distinction would be deceptive. However, the evidence presented to the Boggs court showed a compositional difference. Milk from cows treated with rBST has elevated levels of insulin-like growth factor 1 and contains higher somatic cell counts (International Dairy Foods Association v. Boggs, 2010). The Boggs court declined to defer to the FDA's finding that there was no compositional difference between milk from treated and untreated cows based on this evidence (Beyranevand, 2012)

Given this scientific evidence, the court found two distinct types of milk: milk from cows never given rBST and milk from cows receiving rBST. The compositional distinction required the state to show how precluding the rBST-free label would advance the state's interest in 
preventing consumer deception. The Boggs court concluded that the state's prophylactic ban of composition claims concerning rBST was more extensive than necessary. Any "potential consumer confusion created by the composition claim 'rBST free' could be alleviated by accompanying the claim with a disclaimer informing consumers that rBST has yet to be detected in conventional milk" (International Dairy Foods Association v. Boggs, 2010, p. 639). Under federal law, a government cannot prohibit information that may be potentially misleading if the information can be presented in a way that is not deceptive (In re R.M.J., 1982). The overly restrictive Ohio regulation was invalid under the First Amendment and was subsequently rescinded in 2012 (Ohio Administrative Code, 2012).

The significance of the Boggs judicial decision is that it acknowledges that governmental restrictions on product labeling may be overbroad in regulating free speech (Adler, 2016). The First Amendment seeks to preserve an uninhibited marketplace of ideas in which truth will ultimately prevail and ensure that the government has not regulated speech based on hostility or favoritism toward the underlying message (McCullen v. Coakley, 2014). A government is limited in controlling the content of product labels as vendors should be free to highlight characteristics of products desired by consumers (Adler, 2016).

The limitations on governmental interference in free speech noted by various court decisions provide legal precedents that apply to meat products produced without antibiotics. Since compositional differences exist between meat products sourced from animals treated with antibiotics as opposed to those not treated, the First Amendment supports a conclusion that vendors should be able to claim that the products are antibiotic free. 


\subsection{Distinguishing meat products with respect to the use of antibiotics}

A comparison on labels using "free" with respect to rBST and antibiotics is presented in Table 4. As noted in the table, in 1994 the FDA decided that a claim that a milk product was rBST free was impermissible given the absence of a scientific test to prove the claim. The absence of meaningful tests was also cited by the USDA in precluding claims of antibiotic free. The justification for the government's limitations is that rBST free and antibiotic free may be misleading. With respect to the term rBST free, the FDA felt it falsely connoted a compositional difference. For the term antibiotic free, the USDA feels it suggests that other meat products contain antibiotic residues despite the fact that many products do not.

A label claiming a product is antibiotic free should only be used on products from animals that have never received any therapeutic or nontherapeutic antibiotic. For meat products from animals treated with antibiotics, the distinction is that the products may harbor bacteria genes causing resistance to antibiotics (Voets et al., 2013). Given these features, there is a compositional distinction between meat products from animals never receiving antibiotics. Under judicial interpretations of free speech, the government needs to show how the prohibition of an antibiotic-free label advances a substantial governmental interest (Central Hudson Gas \& Electric Corporation v. Public Service Commission, 1980; Discount Tobacco City \& Lottery, Inc., v. United States, 2012). In addition, it needs to be determined that the regulation is no more extensive than necessary to serve the asserted interest (Central Hudson Gas \& Electric Corporation v. Public Service Commission, 1980).

The Boggs court found no evidence or studies to support consumer confusion other than a few comments in support of banning rBST-free labels. An analogous situation exists for 
antibiotics: no studies or other support of consumer confusion are cited in support of the USDA's prohibition. This suggests that the antibiotic-free label does not deceptively imply that meat products from treated animals contain antibiotics (see International Dairy Foods Association v. Boggs, 2010, p. 638). Furthermore, the prohibition of antibiotic-free labels is more extensive than necessary. For potential confusion involving an rBST-free label, the Boggs court found it could be alleviated by accompanying the claim with a disclaimer informing consumers that rBST has yet to be detected in conventional milk. Likewise, for antibiotic-free labels, potential consumer confusion could be alleviated by accompanying the claim with a disclaimer informing consumers that other meat products may not contain antibiotic residues.

Concern may also exist that the use of an antibiotic-free label would present opportunities for falsely labeling products. However, governments already have remedies for false, deceptive, and mislabeled products (Table 3). Moreover, the USDA could enunciate a rule where the use of an antibiotic-free label needs to be accompanied by verification. The existing Process Verified Program (USDA, 2016a) and the federal organic certification program (U.S. CFR, 2016, tit. 7, part 205) set forth procedures under which animals could be verified as not receiving antibiotics. Moreover, the USDA has enacted other labeling programs to facilitate labeling, such as its Non-Hormone Treated Cattle Program and its Never Fed Beta-Agonists Program (USDA, 2015b, 2015c). These programs offer support for enabling vendors to tell consumers their meat products are antibiotic free.

\section{Conclusion}

Experts feel that antibiotic resistance is a major public health issue. The continued 
availability of antimicrobial drugs for human health "will ultimately depend on the responsible use of these products by all those involved in the authorisation, production, control, distribution and use of antimicrobials in food-producing animals" (Food and Agriculture Organization, 2015, p. 69). Governments around the world might seek opportunities to reduce antibiotic usage to slacken the development of antibiotic-resistant bacteria. One major area is to reduce usage of nontherapeutic antibiotics in animals produced for food. The European Union and the United States have adopted legislative and regulatory provisions to diminish antibiotic usage in agricultural production. Another idea for slackening the development of antibiotic-resistant bacteria is to allow vendors to directly tell consumers that meat products are antibiotic free, meaning the animals supplying these products were not treated with antibiotics. An antibiotic-free label on meat products would allow consumers to express their preference and encourage producers to adopt production practices that eliminate the use of antibiotics.

Due to a number of reasons, countries have policies that fail to encourage the reduction of antibiotic usage. In the United States, the federal policy precluding the use of an antibiotic-free label is an example of an impediment to encouraging the public to help reduce antibiotic usage. The USDA concluded years ago that an antibiotic-free label would deceive consumers. However, subsequent science and a judicial ruling regarding rBST suggest that the USDA's position is flawed. By labeling products as antibiotic free, vendors could allow consumers to select meat products that do not contain antibiotic residues and do not contain bacteria with antibiotic-resistant genes. Whether the USDA will voluntarily amend its position or whether it will require a legal challenge by vendors to change this position remains to be seen.

In an ideal world, countries would come together and adopt an international agreement that 
would establish practices to slacken the use of antibiotics. Absent an international agreement, each country adopts its own regulations over antibiotic usage including labeling information on food products. Countries with the capacity to effectuate regulatory controls can look to the European Union and American provisions for ideas that would phase out antibiotic usage. Countries with consumers who want meat products from animals raised without antibiotics can allow antibiotic-free labels so that the public has a choice. Consumers can select products from animals raised without antibiotics to help reduce antibiotic usage in agricultural production. While these efforts will be spotty and present an uneven playing field, they could help extend the usefulness of antibiotics for future generations.

\section{Acknowledgement}

The research presented here is based on work supported by the Cooperative State Research Education and Extension Service, the U.S. Department of Agriculture Project No. GEO00684.

\section{References}

Abrams, K.M., Meyers, C.A., Irani, T.A., 2010. Naturally confused: Consumers' perceptions of all-natural and organic pork products. Agriculture and Human Values 27, 365-374.

Adler, J.H., 2016. Compelled commercial speech and the consumer "right to know." Arizona Law Review 58, 421-476.

Baron, P.A., Love, D.C., Nachman, K.E., 2014. Pharmaceuticals and personal care products in 
chicken meat and other food animal products: A market-basket pilot study. Sci. Total Environ. 490, 296-300.

Bernárdez, P.F., González, C.F., Batán, J.M., Castro, L.P., Guerra, N.P., 2008. Performance and intestinal coliform counts in weaned piglets fed a probiotic culture (Lactobacillus casei subsp. casei CECT 4043) or an antibiotic. Journal of Food Protection 71(9), 1797-1805.

Beyranevand, L.J., 2012. Milking it: Reconsidering the FDA's refusal to require labeling of dairy products produced from rBST treated cows in light of International Dairy Foods Association v. Boggs. Fordham Environmental Law Review 23, 102-137.

Brewer, M.S., Rojas, M., 2008. Consumer attitudes toward issues in food safety. Journal of Food Safety 28, 1-22.

Brown, L., 2015. Panera ridding food menu of more than 150 artificial ingredients. St. Louis Post-Dispatch (Missouri), 6 May 2015, Section News, p. 1.

Bunge, J., 2015. Pilgrim's expects $25 \%$ of its chicken will be antibiotic-free by 2019: Company is also working to end chicken operations' use of antibiotics needed to fight human illnesses. Wall Street Journal (online), 20 April 2015.

CDC (Centers for Disease Control), 2013. Antibiotic Resistance Threats in the United States, 2013. Atlanta, GA. http://www.cdc.gov/drugresistance/pdf/ar-threats-2013-508.pdf (last accessed 04 May 2016).

Cash, B.A., Rodo’, X., Emch, M., Yunus, M., Faruque, A.S.G., Pascual, M., 2014. Cholera and Shigellosis: Different epidemiology but similar responses to climate variability. PLOS One 9(9), 1-10.

Center for Disease Dynamics, Economics \& Policy, 2016. Antibiotic Resistance. 
http://www.cddep.org/research-area/antibiotic-resistance\#sthash.h5DTN7nA.dpbs (last accessed 04 May 2016).

Centner, T.J., 2008. Regulating the use of non-therapeutic antibiotics in food animals. Georgetown International Environmental Law Review 21(1), 11-36.

Centner, T.J., 2016, Recent government regulations in the United States seek to ensure the effectiveness of antibiotics by limiting their agricultural use. Environment International 92,

Centner, T.J., Lathrop, K.W., 1997. Legislative and legal restrictions on labeling information regarding the use of recombinant bovine somatotropin. Journal of Dairy Science 80, 215-219.

Central Hudson Gas \& Electric Corporation v. Public Service Commission, 1980. 447 U.S. 557 (U.S. Supreme Court).

Cervantes, H.M., 2015. Antibiotic-free poultry production: Is it sustainable? J. Appl. Poult. Res. 24, 91-97.

Consumer Reports, 2012. Meat on Drugs. June 2012. http://www.consumerreports.org/cro/2012/06/antibiotics-are-widely-used-by-u-s-meat-indus try/index.htm (last accessed 04 May 2016).

Detar, J., 2015. Wal-Mart urges its meat suppliers: No antibiotics; follows Tyson, McDonald's. Investor's Business Daily, national edition, 26 May 2015..

Discount Tobacco City \& Lottery, Inc., v. United States, 2012. 674 F.3d 509 (U.S. Sixth Circuit Court of Appeals).

EU Council Regulation, 1998. No 2821/98 of 17 December 1998 amending, as regards 
withdrawal of the authorisation of certain antibiotics, Directive 70/524/EEC concerning additives in feedingstuffs; 1998 OJ L 351.

FDA, 1994. Interim guidance on the voluntary labeling of milk and milk products from cows that have not been treated with recombinant bovine somatotropin. Federal Register 59, 6279-6280.

FDA, 2012. Guidance for Industry: The Judicious Use of Medically Important Antimicrobial Drugs in Food-Producing Animals. No. 209, 13 April 2012.

FDA, 2013. Guidance for Industry: New Animal Drugs and New Animal Drug Combination Products Administered in or on Medicated Feed or Drinking Water of Food-Producing Animals: Recommendations for Drug Sponsors for Voluntarily Aligning Product Use Conditions with GFI \#209. No. 213, December 2013.

FDA, 2015. Veterinary Feed Directive. Federal Register 80(106), 31708-31735.

Food and Agriculture Organization, 2015. Codex Texts of Foodborne Antimicrobial Resistance. Rome, pp. 1-71.

Friends of the Earth, Natural Resources Defense Council, Keep Antibiotics Working, Consumers Union, Center for Food Safety, FACT, 2015. Chain Reaction: How Top Restaurants Rate on Reducing Use of Antibiotics in Their Meat Supply, pp. 1-38.

Gitson v. Trader Joe's Company, 2014. 2014 U.S. Dist. LEXIS 33936 (Federal District Court, Northern District of California).

Hammerum, A.M., Larsen, J., Andersen, V.D., Lester, C.H., Skovgaard Skytte, T.S., Hansen, F., Olsen, S.S., Mordhorst, H., Skov, R.L., Aarestrup, F.M., Agers $\varnothing$, Y., 2014. Characterization of extended-spectrum b-lactamase (ESBL)-producing Escherichia coli obtained from Danish 
pigs, pig farmers and their families from farms with high or no consumption of third- or fourth-generation cephalosporins. J. Antimicrob. Chemother. 69, 2650-2657.

Holmes, A.H., Moore, L.S.P., Sundsfjord, A., Steinbakk, M., Regmi, S., Karkey, A., Guerin, P.J., Piddock, L.J.V., 2015. Understanding the mechanisms and drivers of antimicrobial resistance. The Lancet, DOI: 10.1016/S0140-6736(15)00473-0.

In re R.M.J., 1982. 455 U.S. 191 (U.S. Supreme Court).

International Dairy Foods Association v. Boggs, 2010. 622 F.3d 628-650 (Sixth Circuit Court of Appeals).

Jones, P.J., Marier, E.A., Tranter, R.B., Wu, G., Watson, E., Teale, C.J., 2015. Factors affecting dairy farmers' attitudes towards antimicrobial medicine usage in cattle in England and Wales. Preventive Veterinary Medicine 121(1-2), 30-40.

Key, N., McBride, W.D., 2014. Sub-therapeutic antibiotics and the efficiency of U.S. hog farms. Amer. J. Agr. Econ. 96(3), 831-850.

Kuipers, A., Koops, W.J., Wemmenhove, H., 2016. Antibiotic use in dairy herds in the Netherlands from 2005 to 2012. Journal of Dairy Science 99(2), 1632-1648.

Levitt, T., 2015. Is it time for an antibiotic-free label on our food? The Guardian, 18 June 2015. McCullen v. Coakley, 2014. 134 S. Ct. 2518 (U.S. Supreme Court).

McKendree, M.G.S., Widmar, N.O., Ortega, D.L., Foster, K.A., 2013. Consumer preferences for verified pork-rearing practices in the production of ham products. J. Agric. Resour. Econ. $38,397-417$.

Melvius, D., Heederik, D., 2014. Reduction of antibiotic use in animals 'let's go Dutch'. Journal of Consumer Protection and Food Safety 9, 177-181. 
Merrell Dow Pharmaceuticals Inc. v. Thompson, 1986. 478 U.S. 804 (U.S. Supreme Court).

NRDC (Natural Resources Defense Council), 2014. Raising Resistance: Industrial Production of Livestock-and Antibiotic-Resistant Bacteria that Threaten Human Health. FS 14-04-F, November 2014. https://www.nrdc.org/health/files/raisingresistance.pdf (last accessed 04 May 2016).

Ni, W., Ding, G., Li, Y., Li, H., Liu, Q., Jiang, B., 2014. Effects of the floods on dysentery in north central region of Henan Province, China from 2004 to 2009. Journal of Infection 69, 430-439.

Ohio Administrative Code, 2011. Section 901:11-8-01.

Ohio Administrative Code, 2012. Section 901:11-8-01 (rescinded effective 2 February 2012).

O'Neill, J., 2014. Antimicrobial Resistance: Tackling a Crisis for the Health and Wealth of Nations. UK Welcome Trust. http://amr-review.org/sites/default/files/AMR\%20Review\%20Paper\%20-\%20Tackling\%20a $\% 20$ crisis $\% 20$ for $\% 20$ the $\% 20$ health\%20and\%20wealth\%20of\%20nations_1.pdf (last accessed 04 May 2016).

Ortega, D.L., Wang, H.H., Widmar, N.J.O., 2014. Effects of media headlines on consumer preferences for food safety, quality and environmental attributes. Australian Journal of Agricultural and Resource Economics 59, 433-445.

Paben, B.M., 2015. Lack of interest in consumer interests: FDA's narrow perspective on food labeling and label statements undermines a century of agency leadership. Rutgers Journal of Law \& Public Policy 13, 174-214.

Payne, C.R., Messer, K.D., Kaiser, H.M., 2009. Which consumers are most responsive to 
media-induced food scares? Agricultural and Resource Economics Review 38(3), 295-310.

Perdue Farms, Inc., 2015. Antibiotics Position Statement.

http://perduefarms.com/News_Room/Statements_and_Comments/details.asp?id=545\&title= Antibiotics\%20Position\%20Statement (last accessed 10 May 2016).

Pilgrim's Pride, 2015. Frequently Asked Questions: Do Your Chickens Receive Any Antibiotics? http://www.pilgrims.com/contact-us/faq.aspx (last accessed 04 May 2016).

POM Wonderful LLC v. The Coca-Cola Company, 2014. 134 S. Ct. 2228 (U.S. Supreme Court).

Radis, J.T., 2015. The Lanham Act's wonderful complement to the FDCA: POM Wonderful v. Coca-Cola enhances protection against misleading labeling through integrated regulation. Loyola University Chicago Law Journal 47, 369-435.

Reichl, R., 2014. The F.D.A.'s blatant failure on food. The New York Times, 31 July 2014, Section A, p. 23.

RUMA (Responsible Use of Medicines in Agriculture), undated. Guidelines. http://www.ruma.org.uk/antimicrobials/guidelines/ (last accessed 06 May 2016).

RUMA, 2013. Responsible use of antimicrobials in pig production. http://www.ruma.org.uk/pigs/responsible-use-antimicrobials-pig-production/ (last accessed 06 May 2016).

Sanderson Farms, Inc. v. Tyson Foods, Inc., 2008a. 547 F. Supp. 2d 491 (U.S. Dist. Ct., Md.). Sanderson Farms, Inc. v. Tyson Foods, Inc., 2008b. 549 F. Supp. 2d 708 (U.S. Dist. Ct., Md.). Silva v. Smucker Natural Food, Inc., 2015. 2015 U.S. Dist. LEXIS 122186 (U.S. Dist. Ct., E.D., N.Y.).

Sneeringer, S., MacDonald, J., Key, N., McBride, W., Mathews, K., 2015. Economics of 
Antibiotic Use in U.S. Livestock Production. USDA Economic Research Report No. 2000; November 2015.

Stranieri, S., Banterle, A., 2014. Consumer interest in meat labelled attributes: Who cares? International Food and Agribusiness Management Review 18(4), 21-38.

Strom, S., 2015a. McDonald's to restrict antibiotic use in chicken. The New York Times, international edition, 6 March 2015, Finance, p. 17.

Strom, S., 2015b. Tyson Foods says it plans to eliminate use of human antibiotics in chickens. The New York Times, 29 April 2015, Section B, Business/Financial Desk, p. 2.

Strom, S., 2015c. Poultry's cage match. The New York Times, 1 August 2015, Section B, Business/Financial Desk, sec. B.

Teillant, A., Laxminarayan, R., 2015. Poultry Production. Choices 30(1), 1-11.

Tyson Foods, 2016. Antibiotic Use. http://www.tysonfoods.com/Media/Position-Statements/Antibiotic-Use.aspx (last accessed 04 May 2016).

Umberger, W.J., Boxall, P.C., Lacy, R.C., 2009. Role of credence and health information in determining US consumers' willingness-to-pay for grass-finished beef. Australian Journal of Agricultural and Resource Economics, 53, 603-623.

U.S. CFR (U.S. Code of Federal Regulations), 2016. Title 7, part 205; title 21, sections 510.110, 510.112; title 21, part 556.

U.S. Code, 2012. Title 15, section 1125; title 21, sections 333, 343, 352, 393, 457, 458, 607, 678.

U.S. Statutes, 1938. 52 Statutes 1040.

U.S. Statutes, 1946. 60 Statutes 428. 
USDA, undated. Animal Production Claims: Outline of Current Process. http://www.fsis.usda.gov/OPPDE/larc/Claims/RaisingClaims.pdf (last accessed 04 May 2016).

USDA, 2002. United States Standards for Livestock and Meat Marketing Claims Notice and Request for Comments. Federal Register 67(250), 79552-79556.

USDA, 2015a. Meat and Poultry Labeling Terms. Washington, DC: Food Safety and Inspection Service. http://www.fsis.usda.gov/wps/portal/fsis/topics/food-safety-education/get-answers/food-safe ty-fact-sheets/food-labeling/meat-and-poultry-labeling-terms/meat-and-poultry-labeling-ter ms (last accessed 04 May 2016).

USDA, 2015b. Non-Hormone Treated Cattle Program. http://www.ams.usda.gov/services/imports-exports/nhtc (last accessed 04 May 2016).

USDA, 2015c. Never Fed Beta-Agonists Program. http://www.ams.usda.gov/services/imports-exports/beta-agonists (last accessed 04 May 2016).

USDA, 2016a. Official Listing of Approved USDA Process Verified Programs. http://www.ams.usda.gov/sites/default/files/media/Official\%20ListingPVP.pdf (last accessed 04 May 2016).

USDA, 2016b. USDA Process Verification Program provides non-GMO certification alternative. http://www.foodnavigator-usa.com/Markets/USDA-Process-Verification-Program-is-non-G MO-certification-alternative?utm_source=copyright\&utm_medium=OnSite\&utm_campaign =copyright (last accessed 09 May 2016). 
Valles, S.A. 2015. Bioethics and the framing of climate change's health risks. Bioethics 29(5), 334-341.

Van Boeckel, T.P., Brower, C., Gilbert, M., Grenfell, B.T., Levin, S.A., Robinson, T.P., Teillant, A., Laxminarayan, R., 2015. Global trends in antimicrobial use in food animals. PNAS 112, $5649-5654$.

Visschers, V.H.M., Iten, D.M., Riklin, A., Hartmann, S., Sidler, X., Siegrist, M., 2014. Swiss pig farmers? Perception and usage of antibiotics during the fattening period. Livestock Science $162,223-232$.

Voets, G.M., Fluit, A.C., Scharringa, J., Schapendonk, C., van den Munckhof, T., Leverstein-van Hall, M.A., Stuart, J.C., 2013. Identical plasmid AmpC beta-lactamase genes and plasmid types in E. coli isolates from patients and poultry meat in the Netherlands. International Journal of Food Microbiology 167, 359-362.

Wallinga, D., 2015. The drugs don't work: our post-antibiotic future could already be here; Antibiotic-resistance is killing more than 40,000 people a year in Europe and the US. It is time business helped lead the solutions. The Guardian, Sustainable Business, 18 December 2015.

Wang, Y., Rao, Y., Wu, X., Zhao, H., Chen, J., 2015. A Method for Screening Climate Change-Sensitive Infectious Diseases. Int. J. Environ. Res. Public Health 12, 767-783. WHO (World Health Organization), 2011. Critically Important Antimicrobials for Human Medicine, 3rd Revision. WHO Advisory Group on Integrated Surveillance of Antimicrobial Resistance. Geneva, Switzerland, pp. 1-31.

White House, 2015. National Action Plan for Combating Antibiotic-resistant Bacteria. 
Washington, DC, 1-62.

Wu, G., Day, M.J., Mafura, M.T., Nunez-Garcia, J., Fenner, J.J., Sharma, M., van Essen-Zandbergen, A., Rodríguez, I., Dierikx, C., Kadlec, K., Schink, A.K., Wain, J., Helmuth, R., Guerra, B., Schwarz, S., Threlfall, J., Woodward, M.J., Woodford, N., Coldham, N., Mevius, D., 2013. Comparative analysis of ESBL-positive Escherichia coli isolates from animals and humans from the UK, The Netherlands and Germany. PLoS One 8(9), e75392.

Wyeth v. Levine, 2009. 555 U.S. 555 (U.S. Supreme Court). 
Table 1. Critically and highly important antibiotics.*

\begin{tabular}{|c|c|c|}
\hline Antibiotic & Animal Use & Concerns about the continued use for humans \\
\hline Tetracyclines & Cattle, swine, poultry & Brucella, Chlamydia ssp. and Rickettsia spp. infections \\
\hline Macrolides & Cattle, swine, poultry & $\begin{array}{l}\text { Limited therapy for Legionella, Campylobacter and MDR } \\
\text { Salmonella and Shigella infections; May result from transmission } \\
\text { of Campylobacter spp. and Salmonella from non-human sources }\end{array}$ \\
\hline Aminoglycosides & Swine, poultry & $\begin{array}{l}\text { Transmission of Enterococcus spp., Enterobacteriaceae (including } \\
\text { Escherichia coli) and Mycobacterium spp. from non-human sources }\end{array}$ \\
\hline Sulfonamides & Cattle, swine, poultry & $\begin{array}{l}\text { One of the limited therapies for acute bacterial meningitis, systemic } \\
\text { non-typhoidal salmonella infections and other infections; may } \\
\text { result from transmission of Enterobacteriaceae including E. coli } \\
\text { from non-human sources }\end{array}$ \\
\hline Lincosamides & Swine, poultry & $\begin{array}{l}\text { Human infection may result from transmission of Enterococcus } \\
\text { spp. and Staphylococcus aureus including MRSA from non-human } \\
\text { sources }\end{array}$ \\
\hline
\end{tabular}

*WHO, 2011. 
Table 2. Strategies to reduce usage of antibiotics.

\begin{tabular}{|c|c|c|}
\hline Implementation by & Suggested practice & Citation for the suggestion \\
\hline \multirow[t]{8}{*}{ Producers } & Adoption of best production management practices & RUMA, 2013 \\
\hline & Adoption of good hygiene and pest control programs & RUMA, 2013 \\
\hline & Biosecurity limitations on people and animals & RUMA, 2013 \\
\hline & Following directions and targeted drug usage & RUMA, 2013 \\
\hline & $\begin{array}{l}\text { Improved records on costs of antibiotic usage related } \\
\text { to management practices }\end{array}$ & Visschers et al., 2014 \\
\hline & $\begin{array}{l}\text { Maintenance of herd health plans with preventative } \\
\text { treatments }\end{array}$ & RUMA, 2013 \\
\hline & Maintenance of vaccination programs & RUMA, 2013 \\
\hline & Use of probiotics as an alternative to antibiotics & $\begin{array}{l}\text { Bernárdez et al., 2008; Cervantes, } \\
2016\end{array}$ \\
\hline \multirow[t]{3}{*}{ Veterinarians } & Educational efforts with producers & $\begin{array}{l}\text { Jones et al., 2015; Kuipers et al., } \\
2016\end{array}$ \\
\hline & $\begin{array}{l}\text { Refraining from prescribing third- and fourth- } \\
\text { generation drugs }\end{array}$ & $\begin{array}{l}\text { Kuipers et al., 2016; Melvius and } \\
\text { Heederik, } 2014\end{array}$ \\
\hline & $\begin{array}{l}\text { Sufficient knowledge of clients' situations to prescribe } \\
\text { minimal drug usage needed for therapy }\end{array}$ & Kuipers et al., 2016 \\
\hline \multirow{5}{*}{$\begin{array}{l}\text { Governments and } \\
\text { non-governmental } \\
\text { organizations }\end{array}$} & Educational efforts with producers & Jones et al., 2015 \\
\hline & Product labeling & USDA, 2016a \\
\hline & $\begin{array}{l}\text { Provide cost projections related to practices to reduce } \\
\text { usage }\end{array}$ & Visschers et al., 2014 \\
\hline & Provide financial rewards for reduced usage & Visschers et al., 2014 \\
\hline & Surveillance and monitoring of usage & $\begin{array}{l}\text { Kuipers et al., 2016; Visschers et } \\
\text { al., } 2014\end{array}$ \\
\hline
\end{tabular}


Table 3. Comparisons of the statutory directives for meat and poultry labeling.

\begin{tabular}{|c|c|c|c|}
\hline & $\begin{array}{l}\text { Federal Food, Drug, \& } \\
\text { Cosmetic Act, U.S. Code tit. } \\
21, \S \S 343,393\end{array}$ & $\begin{array}{l}\text { Lanham Act, U.S. Code tit. 15, } \\
\S 1125\end{array}$ & $\begin{array}{l}\text { Meat and poultry labeling, } \\
\text { U.S. Code tit. } 21, \S \S 457 \& \\
607\end{array}$ \\
\hline Command & the administration shall ensure & any person & the secretary may prescribe \\
\hline Subject & $\begin{array}{l}\text { foods are safe } \ldots \text { and properly } \\
\text { labeled }\end{array}$ & $\begin{array}{l}\text { false designation or misleading } \\
\text { representation }\end{array}$ & standards of identity \\
\hline When or how & misbranded food & $\begin{array}{l}\text { in commercial advertising or } \\
\text { promotion }\end{array}$ & in labeling \\
\hline $\begin{array}{l}\text { Protection } \\
\text { accorded }\end{array}$ & $\begin{array}{l}\text { against false or misleading } \\
\text { labels }\end{array}$ & $\begin{array}{l}\text { false designations and } \\
\text { misleading representations }\end{array}$ & $\begin{array}{l}\text { to avoid false or misleading } \\
\text { labeling }\end{array}$ \\
\hline $\begin{array}{l}\text { Action } \\
\text { authorized }\end{array}$ & $\begin{array}{l}\text { review applications and } \\
\text { submissions }\end{array}$ & shall be liable in a civil action & $\begin{array}{l}\text { direct or withhold approval of } \\
\text { labeling }\end{array}$ \\
\hline
\end{tabular}


Table 4. Comparison of labels using "free" with respect to rbST and antibiotics.

\begin{tabular}{|c|c|c|}
\hline Feature & $\mathrm{rbST}$ & Antibiotics \\
\hline Prohibition on labels using "free" & $\begin{array}{l}\text { FDA, 1994: cannot say "rbST } \\
\text { free" }\end{array}$ & $\begin{array}{l}\text { USDA, 2002: cannot say } \\
\text { "antibiotic free" }\end{array}$ \\
\hline Government's argument & no scientific test to prove & no scientific test to prove \\
\hline $\begin{array}{l}\text { Justification for finding "free" to } \\
\text { be misleading }\end{array}$ & $\begin{array}{l}\text { falsely connotes a compositional } \\
\text { difference }\end{array}$ & $\begin{array}{l}\text { inaccurately infers that meat from } \\
\text { animals treated with antibiiotics } \\
\text { have residues }\end{array}$ \\
\hline First Amendment claim & $\begin{array}{l}\text { unjustified limitation on free } \\
\text { speech }\end{array}$ & $\begin{array}{l}\text { unjustified limitation on free } \\
\text { speech }\end{array}$ \\
\hline Government's concern & $\begin{array}{l}\text { milk from treated and untreated } \\
\text { cows is the same }\end{array}$ & $\begin{array}{l}\text { meats from untreated and treated } \\
\text { animals are the same }\end{array}$ \\
\hline $\begin{array}{l}\text { New proof of a distinction } \\
\text { between products }\end{array}$ & $\begin{array}{l}\text { compositional differences in } \\
\text { insulin-like growth factor and } \\
\text { higher somatic cell count }\end{array}$ & $\begin{array}{l}\text { some meat products have residues } \\
\text { and meats may harbor genes } \\
\text { causing resistance to antibiotics }\end{array}$ \\
\hline $\begin{array}{l}\text { The government's prohibition is } \\
\text { more extensive than necessary }\end{array}$ & yes, attach a disclaimer & $\begin{array}{l}\text { yes, attach a disclaimer or } \\
\text { institute a verification program }\end{array}$ \\
\hline
\end{tabular}

